\title{
STRENGTH ASPECTS OF FLY ASH IN CEMENT MORTAR
}

\author{
Priji E. Moses
}

$\mathrm{PhD}$-Scholar, Department of Civil Engineering, Bharath Institute of Higher Education and Research (BIHER), Chennai, India.

\section{Dr. M.P. Chockalingam*}

Professors, Department of Civil Engineering, Bharath Institute of Higher Education and Research (BIHER), Chennai, India.

\section{Dr. R. Venkatakrishnaiah}

Professors, Department of Civil Engineering, Bharath Institute of Higher Education and Research (BIHER), Chennai, India.

\section{Prof. P. Dayakar}

Professors, Department of Civil Engineering Bharath Institute of Higher Education and Research (BIHER), Chennai, India. *Corresponding Author : chockalingammp@gmail.com

\begin{abstract}
The aim of the investigation was to evaluate the feasibility of mixing fly ash in cement to make mortar specimens for getting an agreeable compressive Strength of the mortar. Different proportions of cement and fly ash were tried at laboratory-scale, utilizing dry fly ash at 15\%, 20\%, 25\%, 30\%, 35\%, 40\%, 45\% and 50\% of cementweight. The reference mortar was prepared with $100 \%$ of Ordinary Portland Cement $(O P C)$. The blended mortar was utilized to make standard cubes of uniform size, namely, $70.6 \mathrm{~mm}(\mathrm{~L}), 70.6 \mathrm{~mm}(\mathrm{~W})$ and $70.6 \mathrm{~mm}(\mathrm{H})$. After curing at standard temperature and humidity, being soaked in potable water, tests were carried out, for evaluating the compressive strengths attained by the cube specimens, at the curing ages of 3, 7, 14, 21 and 28 days.

The $28^{\text {th }}$ day's compressive strength of the cement-fly-ash-mortar containing $70 \%$ cement and $30 \%$ fly ash was 37.53N/sq.mm, which corresponded to $93.7 \%$ of the Compressive strength(40.06N/sq.mm) attained by the reference mortar which contained $100.0 \%$ of cement. and zero percent

It was inferred that fly ash can be added at 30\% weight of cement in the mortar, on dry weight basis.
\end{abstract}

Keywords: Cement, Mortar, Fly Ash, Test on Compressive Strength, Optimum Ratio 
Cite this Article: Priji E. Moses, Dr. M.P. Chockalingam, Dr. R. Venkatakrishnaiah, P. Dayakar, Strength Aspects of Fly Ash in Cement Mortar, International Journal of Advanced Research in Engineering and Technology (IJARET), 11 (1), 2020, pp 38-44. http://iaeme.com/Home/issue/IJARET?Volume=11\&Issue=1

\section{INTRODUCTION}

Portland Cement, generally referred to as Ordinary Portland Cement (OPC) is the popular ingredient in making a mortar, along with sand and water (1). Manufacturing of cement causes the emission of excessive Carbon dioxide (CO2), along with other polluting materials such as dust (Particulate Matter), and other harmful gases. For this reason, alternative material which can substitute cement needs to be tested and evaluated $(2,3,4)$. 'Fly ash' obtained from coal-burnt Thermal Power Plants, is one such material which may be used along with cement, in making a mortar or concrete. There could be some advantage from the view point of economic savings, energy savings, without losing technical advantage (4). Fly ash, as a substance possessing cementitious ingredients, can supplement the bonding action in the mortar or concrete (5).

The mixing of fly as with cement in making a mortar, or use in the concrete has been reported to increase pozzolanic quality (containing silicious and aluminous compounds). Adding water to cement initiates the hydration process, involving an exo-thermic reaction, generating heat in the mix. Calcium Silicate Hydrate, a product of cement hydration, will undergo Pozzolnic reaction with fly-ash, if it is added. As a result, strength development and increase in durability are achieved $(6,7.8,9)$.

\subsection{Hydration Process and Its Impact on Binding Products}

Hydration generally describes the physical and chemical processes which take place when water is added to cement. As a result of hydration, Silicates and Aluminates are yielded, forming a hardened mass called 'hydrated cement'. It is achieved by an Exothermic Reaction when cement and fly ash are mixed with water. Subsequently, a pozzolanic activity gets initiated, producing the same kind of cementitious compounds, similar to the cementhydration process $(10)$. However, the rate of reaction with fly ash is considered as a slow process in so far as the rate at which the strength is gained by the resulting mass. For this reason, perhaps, the re-use of fly ash, in the manufacture of 'Pozzolanic Portland Cement' has not increased significantly(11).

It is further learnt that the 'Free Lime $(\mathrm{CaOH})$ ' liberated during the hydration process of cement and water is going to be beneficial when fly ash is added as a third ingredient, to result in the formation of a 'durable binder', namely, called Calcium Silicate Hydrate(8).

In order to curtail environmental pollution caused by other methods of disposing fly-ash, the scheme of producing Pozzolana Portland Cement has been introduced in many cement manufacturing companies around the world $(10,11)$.

\section{ROLE OF RESEARCH}

Research findings in the effort of finding alternate materials to replace cement, or substituting cement in its use, at least partially, wherever possible, is considered as a contribution to the society, due to the well-established statistical facts relating to the quantum of cement manufacture, at the global scale, and the seriousness of environmental pollution related to cement production, in view of carbon dioxide-emissions and other green house gases (12). Encouraging results in partial replacement of cement by Fly Ash have been shown, in developing strength and durability in concrete (13). This has formed the basis of interest to take up the present Study. 


\section{AIM AND OBJECTIVE OF THE STUDY}

The aim of the Study was to evaluate the optimum percentage of fly ash which can be reliably used in cement concrete, without sacrificing strength aspects in construction works. The scope of the study is that the results of the study can be successfully put into field-practice.

\section{METHODOLOGY}

Laboratory Studies were conducted to cast sufficient number of mortar specimens, in predetermined mix proportions. Relevant IS-codes were followed in carrying out the necessary experiments for each parameter chosen for the study. The ratio of mortar mix was selected as cement : sand $=1: 3$. The Reference Mortar containing 100\% cement. Varying percentages of Fly Ash were added in the mortar, to replace cement, at $15 \%, 20 \%, 25 \%, 30 \%, 35 \%, 40 \%$, $45 \%$, and $50 \%$ weight of cement. The quantity of fine aggregate (sand) remained the same. The specimens of mortar were cast in the moulds of standard size, to produce specimen prototypes of size $70.6 \mathrm{~mm}(\mathrm{~L}), 70.6 \mathrm{~mm}(\mathrm{~W}), 70.6 \mathrm{~mm}(\mathrm{H})$. After removing the specimens from the moulds, they were kept under controlled laboratory conditions, maintaining a constant temperature of $27{ }^{\circ} \mathrm{C}$ and a relative humidity of $90 \%$, for a period of 24 hours, and then kept in the curing yard under shade. They were subjected to testing for compressive test during the Curing age of 3, 7, 21 and 28 days.

\section{RESULTS}

Table-1 presents a comparison of Physical and Chemical characteristics of Ordinary Portland Cement (OPC) and Fly Ash.

Table 1 Physical and Chemical Characteristics of OPC and fly ash

\begin{tabular}{|l|c|c|}
\hline \multicolumn{1}{|c|}{ Physical Parameters } & OPC & Fly Ash \\
\hline (i) Fineness & & $98.12 \%$ \\
\hline Passing 0.075 mm Sieve, (\%) & $94.2 \%$ & 380 \\
\hline Specific Surface area (sq.m/kg) & 330 & -- \\
\hline Specific Gravity & 3.12 & 6.98 \\
\hline Chemical ingredients (\%) & & 53.77 \\
\hline CaO (Calcium Oxide) & 56.12 & 20.43 \\
\hline SiO2 (Silicon Di-Oxide) & 19.06 & 4.98 \\
\hline Al2O3 (Aluminium Oxide) & 5.02 & .36 \\
\hline Fe2O3 (Ferric Oxide) & 2.73 & 0.19 \\
\hline MgO (Magnesium Oxide) & 1.98 & 3.13 \\
\hline SO3 (Sulphur Tri-oxide) & 0.97 & -- \\
\hline Na2O (Sodium Oxide) & -- & -- \\
\hline Ignition Loss & 1.04 & 9.87 \\
\hline Residue (Insoluble) & 0.57 & -- \\
\hline Lime Reactivity & - & \\
\hline
\end{tabular}

Note : Portland Cement Association (PCA) has categorized Fly Ash as follows: Type - F, Type-Cl, and Type- $\mathrm{CH}$, based on percentage content of $\mathrm{CaO}$ (Calcium Oxide).

Type-F contains less than $8 \% \mathrm{CaO}$; Type-CI contains $8 \%$ to $20 \% \mathrm{CaO}$; and Type- $\mathrm{CH}$ contains greater than $20 \% \mathrm{CaO}$. (PCA-Publication, 2015). 
Table-2 presents the percentage of grains finer than the respective sieve sizes.

Table 2 Grain size distribution of fine aggregate

\begin{tabular}{|c|c|c|}
\hline Sieve Size & \% finer & \\
\hline 4750 um & 99.2 & \\
\hline 1700 um & 98.14 & \\
\hline 1180 um & 97.56 & \\
\hline $425 \mathrm{um}$ & 91.27 & \\
\hline $300 \mathrm{um}$ & 92.11 & \\
\hline $212 \mathrm{um}$ & 80.33 & -- \\
\hline $150 \mathrm{um}$ & 59.23 & \\
\hline $75 \mathrm{um}$ & 36.75 & \\
\hline
\end{tabular}

Table- 3 presents the compressive strengths attained by the Reference mortar (containing $100 \%$ cement in the $1: 3$ cement-sand mortar), and the 8 -other mixes containing $15 \%$ of flyash substitute for cement, $20 \%, 25 \%, 30 \%, 35 \%, 40 \%, 45 \%$ and $50 \%$ fly-ash contents.

Table 3 Variationof Percentages of Compressive Strength (N/sq.mm) against Fly ash percentages achieved during different Curing Ages

\begin{tabular}{|c|c|c|c|c|c|c|}
\hline $\begin{array}{c}\text { SI } \\
\text { No }\end{array}$ & Fly ash \% & $\begin{array}{c}\text { 3days } \\
\text { CS }\end{array}$ & $\begin{array}{c}\mathbf{7} \text { days } \\
\text { CS }\end{array}$ & $\begin{array}{c}\mathbf{1 4} \text { days } \\
\text { CS }\end{array}$ & $\begin{array}{c}\mathbf{2 1} \text { days } \\
\text { CS }\end{array}$ & $\begin{array}{c}\mathbf{2 8} \text { days } \\
\text { CS }\end{array}$ \\
\hline 1 & 0.00 & 29.2 & 33.6 & 36.6 & 38.0 & 40.06 \\
\hline 2 & 15.00 & 24.82 & 29.13 & 31.18 & 33.50 & 34.13 \\
\hline 3 & 20.00 & 22.01 & 24.02 & 29.32 & 33.41 & 35.57 \\
\hline 4 & 25.00 & 26.57 & 30.57 & 33.32 & 35.34 & 36.65 \\
\hline 5 & 30.00 & 27.42 & 30.12 & 33.32 & 35.91 & 37.53 \\
\hline 6 & 35.00 & 26.98 & 30.01 & 32.97 & 34.93 & 36.35 \\
\hline 7 & 40.00 & 27.01 & 29.47 & 32.67 & 33.08 & 33.98 \\
\hline 8 & 45.00 & 27.98 & 30.06 & 31.98 & 32.17 & 32.38 \\
\hline 9 & 50.00 & 27.97 & 31.17 & 32.04 & 32.27 & 32.87 \\
\hline
\end{tabular}

The Cement mortar with sand and $100.0 \%$ cement attains compressive strengths of 29.2 $\mathrm{N} / \mathrm{sq} . \mathrm{mm}, 33.6 \mathrm{~N} / \mathrm{sq} . \mathrm{mm}, 36.6 \mathrm{~N} / \mathrm{sq} . \mathrm{mm}, 38.0 \mathrm{~N} / \mathrm{sq} . \mathrm{mm}$, and $40.06 \mathrm{~N} / \mathrm{sq} . \mathrm{mm}$, respectively, on the Curing Ages of 3days, 7days, 14days, 21days and 28days. The Compressive strengths of Mortars containing varying percentages Fly Ash, namely, 15\%, 20\%, 25\%, 30\%, 35\%, 40\%, $45 \%$ and $50 \%$, are shown in Table-3, corresponding to the Curing Ages varying from 3 days to 28days.

The Compressive Strength of Fly Ash-Cement mortar containing 30\% of Fly Ash ( and $70 \%$ of Cement) attains the maximum value of $37.53 \mathrm{~N} / \mathrm{sq} . \mathrm{mm}$, on the $28^{\text {th }}$ day of Curing Age, among all the Fly Ash-Cement mortars used in the Study. This means that $30.0 \%$ of Cement weight is the Optimum Fly Ash quantum which can be added in the mortar, to give the maximum Compressive Strength. This variation is shown in Table-4 and depicted in Figure-1. 
Table 4 Variation of Compressive Strength of Fly-ash mortars as a percentage of Reference Mortar

\begin{tabular}{|c|c|c|}
\hline S No & Fly ash (\%) & $\begin{array}{c}\mathbf{2 8} \text { days } \\
\text { CS }\end{array}$ \\
\hline 1 & 0.00 & 100 \\
\hline 2 & 15.00 & 85.2 \\
\hline 3 & 20.00 & 88.8 \\
\hline 4 & 25.00 & 91.5 \\
\hline 5 & 30.00 & 93.7 \\
\hline 6 & 35.00 & 93.5 \\
\hline 7 & 40.00 & 88.8 \\
\hline 8 & 45.00 & 84.8 \\
\hline 9 & 50.00 & 71.8 \\
\hline
\end{tabular}

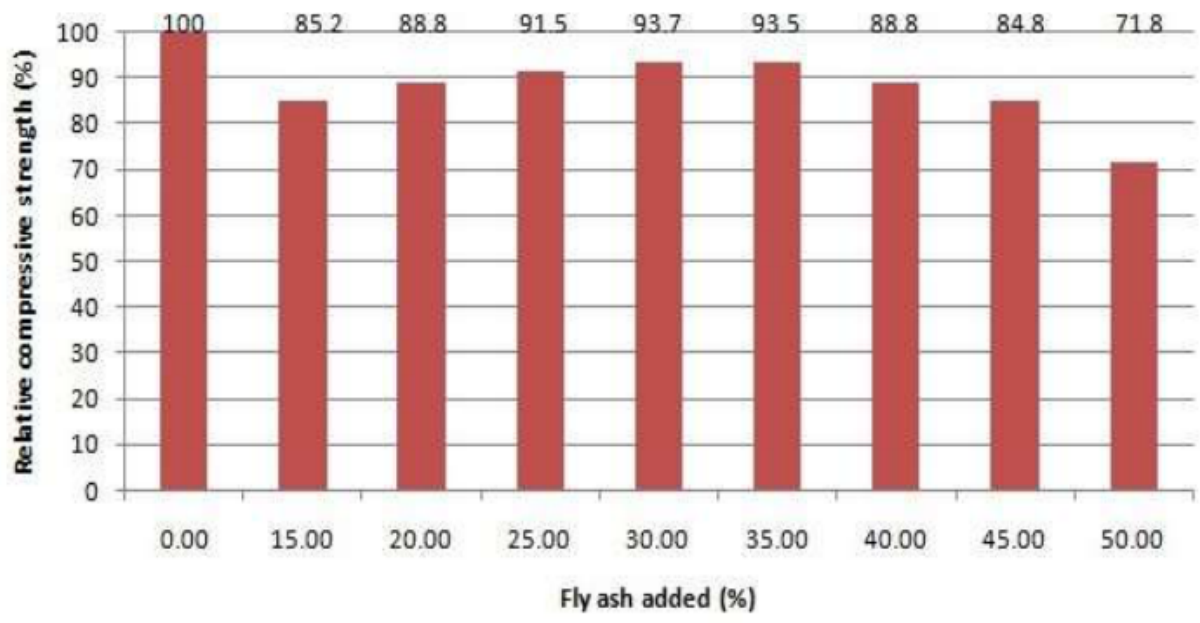

Figure 1 Variation of Compressive Strength percentages in Mortars containing Fly-Ash in contrast to Reference Mortar

\section{CONCLUSIONS}

Based on laboratory-scale studies on comparing the compressive strengths developed by cement mortars, using $100 \%$ cement in the first case, versus partially substituting cement by adding fly ash, in varying percentages, namely, $15 \%$ to $50 \%$, in steps of $5 \%$, the following results were revealed :

(i) The Cement mortar containing $100 \%$ cement with sand and water attained a compressive strength of $40.06 \mathrm{~N} / \mathrm{sq} . \mathrm{mm}$.

(ii) Trials of substituting cement with Fly ash proved that $30 \%$ of cement weight is the optimum Fly ash addition at which maximum compressive strength is attained, which was equal to $93.7 \%$ of the compressive strength attained by the Reference Mortar. .

(iii) Optimum percentage of Fly ash added can be encouraged up to $30 \%$ of the weight of cement, in making the mortar, from the view-point of achieving a favourable compressive strength.

(iv) There is evidence in the literature to show that the quality characteristics of Fly Ash, which obtained from Coal-burning Thermal Power Plants, can be different, depending on the nature of combustion processes employed, and the type of fuels used, and hence, it becomes necessary to generate data locally to optimize on the re-use of coal $(14,15,16)$. 


\section{REFERENCES}

[1] Tarun, R. Naik., Shiw, S. Singh., and Mohammad, M. Hossain., Permeability of High Strength Concrete Containing Low Cement Factor, Journal of Energy Engineering, 1996, 122 (1), pp.21-39.

[2] Min-Hong, Zhang., Marcia, C. Blanchette., and V, M. Malhotra., Leachability of Trace Metal Elements from Fly Ash Concrete: Results form Column-Leaching and Batch Leaching Tests, ACI Materials Journal, 2001, 98 (2),pp.126-136.

[3] Ozkan, Sengul., and Mehmet, Ali. Tasdemir., 2009, Compressive Strength and Rapid Chloride Permeability of Concretes with Ground Fly Ash and Slag, Journal of Materials in Civil Engineering, 2009, 21 (9), pp.494-501.

[4] Malhotra, V. M., Role of Supplementary Commentating Materials in Reducing Greenhouse Gas Emission, MTL Division Report, Natural Resources Canada, 1988, Ottawa,pp.17.

[5] Elkhadiri, I., Diouri, A., Boukhari.A., Aride, J., Puertas, F., Mechanical behavior of various mortars made by combined fly ash and limestone in Moroccan Portland cement, Cement and Concrete Research, 2002, 32, pp.1597-1603.

[6] Poon, C. S., Lam, L., Wong, Y. L., A Study on High Strength Concrete Prepared with Large Volumes of low Calcium Fly Ash, Cement and Concrete Research, 2002, 30 (3), pp. 447-455.

[7] Sanchez, E., Massana, J., Garcimartin, M.A., Moragues, A., 2008, Mechanical strength and microstructure evaluation of fly ash cement mortar submerged in pig slurry, Cement and Concrete Research, 2008, 38, pp. 717-724,

[8] Papadakis, V. G., Tsimas, S., Supplementary Cementing Materials in Concrete Part I: Efficiency and design, Cement and Concrete Research, 2002, 32,pp. 1525-1532.

[9] Oner, A., Akyuz, S., Yildiz, R., An Experimental Study on Strength Development of Concrete Containing Fly Ash and Optimum Usage of Fly Ash in Concrete, Cement and Concrete Research, 2005, 35, pp.1165-1171.

[10] Serdar, Aydin., Bulent, Baradan., Effect of Pumice and Fly Ash incorporation on High Temperature Resistance of Cement Based Mortars, Cement and Concrete Research, 2007, 37, pp.988-995.

[11] Rafat Siddique, 2003, Effect of Fine Aggregate Replacement with Class F Fly Ash on the Mechanical Properties of Concrete, Cement and Concrete Research, 2003, 33 (4), pp. 539547.

[12] Alain, Bilodeau., and V, Mohan. Malhotra., High-Volume Fly Ash System: Concrete Solution for Sustainable Development, ACI Materials Journal, 2000, 97 (1),pp.41-47.ark, Reiner., and Kevn, Rens., High-Volume Fly Ash Concrete: Analysis and Application, Practice Periodical on Structural Design and Construction, 2006, 11 (1), pp.58-64.

[13] ASTM C 150-86, Standard Specification for Portland Cement, Annual Book of ASTM Standards, 1988, (Vol. 4.01-Cements, Lime, Gypsum), Easton, USA.

[14] Malik, M., Soni, N.K., et.al, 2016, "Fly ash from coal-fired thermal Power Plants using Energy Dispersive X-Ray Flouroscence Spectrometry", Scientific Reviews and Chemical Communications", 6(4) : 91-101.

[15] Sadasuvan, S., and Negi, B.S., 1991,"Chemical Characteristics of Fly ash from Coal Burnt/ Coal-fired Thermal Power Plants in India", Sci. Total Environ., 103 : 151-158.

[16] Wei, Y., Wang, Q., et.al, 2015, "Characteristics and Utilisation of Fly Ash from coal-fired power plant in China", 2015-World of Coal Ash (WOCA) Conference in Nashville, TN, U.S.A., May 5-7, 2015. (http://www.flyash.info).

[17] Bureau of Indian Standards, IS : 4031(Part 6)-1988 (Re-affirmed 2005). Methods of Physical Tests for Hydraulic Cement (Part 6: Determination of Hydraulic Cement other than Masonry Cement), UDC 666.94.539.411. 
[18] Lakshmi P.S, Dr. B.S. Jayashankar Babu, Dr. N.C. Balaji, Chaithra G.B, Influence of Bagasse Ash Replacement on Strength Properties of Cement Mortar, International Journal of Civil Engineering and Technology, 10(5), 2019, pp. 954-962

[19] Diana Alice Sugunan, G.Balamurali and S.Muthulakshmi, Study on Soil Stabilization Using Cement and Fly Ash, International Journal of Civil Engineering and Technology, 9(11), 2018, pp. 1236-1243

[20] P. Munusamy, R. Balaji and C. Sivakandhan, Analysis of Sand Mold Using Industrial Powders and Fly Ash. International Journal of Mechanical Engineering and Technology, 8(1), 2017, pp. 292-303

[21] Saloma, Hanafiah and Dea Risti Andani, Analysis of Microstructure of Foamed Concrete with Variation Curing Temperature and Fly Ash, International Journal of Mechanical Engineering and Technology, 9(9), 2018, pp. 329-337. 